\title{
Further Molecular Characterization and Effect on Host Photosynthetic Pigments and Carbohydrate Pools of an Egyptian Isolate of TBSV
}

\author{
Faiza A. Fattouh ${ }^{1}$, Awatif S. Ali ${ }^{2 *}$ and Radwa M. Fathy ${ }^{2}$
}

${ }^{1}$ Department of Botany and Microbiology, Faculty of Science, Alexandria University, Egypt

${ }^{2}$ Department of Botany, Faculty of Science, Damanhour University, Egypt

\begin{abstract}
The Egyptian isolate of Tomato bushy stunt virus, the TBSV Egh was further characterized with respect to its coat protein gene (P42CP), movement protein gene (P22MP) and replication protein gene (P33RP). All 3 genes were amplified by PCR from TBSV Egh purified virus. Both P42CP and P22MP were further cloned, partially sequenced and deposited into the gene bank under accession numbers HM439101 NCBI and JX418297 respectively. Phylogenetic analysis illustrates evolutionary relationship between TBSV Egh P22 and P42 partial sequence indicated that this isolate may represent a new different strain of TBSV. Loss in chlorophyll content of TBSV Egh infected Lycopersicon esculentum and Cucurbita pepo hosts are reported. Variable significant differences in glucose, sucrose and polysaccharides have been observed.
\end{abstract}

Keywords: Tomato bushy stunt virus; Genome sequence; Carbohydrate pools; Phylogentic analysis

\section{Introduction}

Tomato bushy stunt virus is among the viruses reported to infect the tomato crop in Egypt. A TBSV Egh has been previously identified [1]. Tombusviruses are known to have four Open Reading Frames (Orfs) encoded on the monopartite ssRNA genome of about $4.7 \mathrm{~Kb}$ [2]. ORF 1 encodes a $33 \mathrm{KDa}$ protein terminated by an amber termination codon which is read-through to give a protein of $92 \mathrm{KDa}$ (ORF1RT). Both proteins form the RNA-dependent RNA-polymerase (RdRp). The $40 \mathrm{KDa}$ CP is expressed from subgenomic (sg) RNA $1(2,2 \mathrm{~Kb})$ and is the product of ORF 2 [3]. ORF 3 and ORF 4 are expressed from sgRNA $2(0,9 \mathrm{~Kb})$. The product of ORF $3(22 \mathrm{KDa})$ is responsible for cell to cell movement. ORF 4 is embedded inside ORF 3 and codes for a protein of about $19 \mathrm{KDa}$ which regulates symptom expression $[4,5]$ and was identified to be a counterpart of the post transcriptional gene silencing system [6].

The translation of the nested P22 and P19 genes from sgRNA2 occurs via context-dependent ribosome leaky scanning $[7,8]$. The important features for this process are a relatively short untranslated leader sequence on sgRNA2, a suboptimal translation initiation context surrounding the AUG of P22, and close proximity of the downstream AUG for P19 that is positioned in an optimal context for initiation of translation [7].

The P33 and P92 proteins encoded by TBSV are required for its replication in planta [9]. The P33/P92-containing replicase complex uses the gRNA as a template for synthesis of a complementary minussense RNA that can be purified to high amounts from infected plants in association with plus-sense RNA, as double-stranded RNA (dsRNA). The minus-sense RNA, perhaps while associated with dsRNA, serves as the template for progeny plus-sense RNA. P33 preferentially binds single-stranded nucleic acid [10], which is a property, shared with many other plant viral proteins, such as movement and coat proteins. The RNA-binding by P33 has been mapped to an arginine/prolinerich motif and mutations within this motif in P33 affect gRNA and sgRNA synthesis [11] and RNA recombination [10]. P33 binds RNA in a cooperative manner, which suggests that upon binding of the first P33 unit, the RNA is rapidly coated with additional P33 molecules. The coating of the viral ssRNAs may be beneficial during template recruitment by P92 and/or during the replication process itself [12]. Alternatively, the P33-coated viral RNAs may be more resistant to nucleases and less accessible to host-mediated gene silencing than are free viral RNAs [10,12].

Chlorophylls can directly determine photosynthetic potential and primary production as they function to absorb solar radiation and give an indirect estimation of the nutrient status because much of leaf nitrogen is incorporated in their structure [13,14]. It is even probable that the virus impairs plant performance through limiting photosynthetic production. Frequently disturbance in respiration, photosynthetic efficiency and the partitioning of carbon between starch, soluble sugars, organic and amino acids was take place in both directly inoculated and systemically infected tissues $[15,16]$. The alterations in carbohydrate metabolism frequently result in the occurrence of starch lesions or ring spots at viral infection sites and abnormal accumulation or depletion of this important storage compound in systemically infected tissues, [17]. Viral infection could cause alterations in physiological function via: (a) plant viruses can exert specific control over expression of host mRNA [18], and (b) that viral movement proteins (MP) have evolved the capacity to interact with an endogenous plasmodesmal macromolecular trafficking system [19].

The aim of this investigation is to perform a molecular study on genes of an Egyptian TBSV isolate namely P42, P22 and P33 genes and investigation into physiological effects associated with infection of the isolate onto two different hosts of the virus namely, Lycopersicon esculentum and Cucurbita pepo. The TBSV isolate will be characterized with respect to genomic nucleic acid size and specific genes of the

*Corresponding author: Awatif S. Ali, Department of Botany, Faculty of Science, Damanhour University, Egypt, Tel: +020-01281194206; E-mail: awatifali95@yahoo.com

Received November 07, 2014; Accepted April 15, 2015; Published April 20, 2015

Citation: Fattouh FA, Ali AS, Fathy RM (2015) Further Molecular Characterization and Effect on Host Photosynthetic Pigments and Carbohydrate Pools of an Egyptian Isolate of TBSV. J Plant Pathol Microb 6: 261. doi:10.4172/2157-7471.1000261

Copyright: (c) 2015 Fattouh FA, et al. This is an open-access article distributed under the terms of the Creative Commons Attribution License, which permits unrestricted use, distribution, and reproduction in any medium, provided the original author and source are credited. 
Citation: Fattouh FA, Ali AS, Fathy RM (2015) Further Molecular Characterization and Effect on Host Photosynthetic Pigments and Carbohydrate Pools of an Egyptian Isolate of TBSV. J Plant Pathol Microb 6: 261. doi:10.4172/2157-7471.1000261

viral genome will be cloned into appropriate vectors, sequenced and its genetic relationship to other known TBSV isolates determined. Alternation in photosynthetic pigments and carbohydrates pools contents of infected plants will also be investigated.

\section{Materials and Methods}

\section{Extraction of genomic viral RNA of TBSV Egh}

TBSV Egh virus was propagated, isolated and purified as indicated previously [1]. Extraction of genomic viral RNA was performed by QIAamp Viral RNA Mini column for purification of viral RNA (Qiagen Int; USA). To $140 \mu \mathrm{l}$ of pure virus in $1.5 \mathrm{ml}$ micro centrifuge tube, $560 \mu \mathrm{l}$ of prepared Buffer AVL containing carrier RNA were added, then mixed by pulse-vortexing for $15 \mathrm{~s}$ and were centrifuged at $12,000 \mathrm{rpm}$ for $10 \mathrm{~min}$. The supernatant was incubated in new clean tubes at room temperature $\left(15-25^{\circ} \mathrm{C}\right)$ for $10 \mathrm{~min}$. The sample was centrifuged to remove drops from the inside of the lid. $560 \mu \mathrm{l}$ ethanol (96-100\%) was added to the sample, mixed by pulse-vortexing for 15 $\mathrm{s}$ and centrifuged to remove drops from the inside of the lid. $630 \mu \mathrm{l}$ from this solution were pipetted into the QIAamp Mini spin columns and centrifuged at $8,000 \mathrm{rpm}$ for $1 \mathrm{~min}$. The spin columns were placed into a clean $2 \mathrm{ml}$ collection tube, and the tubes containing the filtrate were discarded. $500 \mu \mathrm{l}$ of buffer AW1 was added to each tube, and centrifuged at $8,000 \mathrm{rpm}$ for $1 \mathrm{~min}$. Each spin column was placed into a clean $2 \mathrm{ml}$ collection tube. $500 \mu \mathrm{l}$ of buffer AW2 was added, each one of the tubes was centrifuged at full speed $14,000 \mathrm{rpm}$ for $3 \mathrm{~min}$. The tubes were further centrifuged at full speed for $1 \mathrm{~min}$. The mini spin columns were placed into a new $1.5 \mathrm{ml}$ microfuge tubes, and the collection tube with filtrate were discarded. $60 \mu \mathrm{l}$ of buffer AVE (RNase-free water contains $0.04 \%$ sodium azide) were added followed by incubation at room temperature for $1 \mathrm{~min}$. As a final step of isolation, the viral RNA from each tube was centrifuged at $8,000 \mathrm{rpm}$ for $1 \mathrm{~min}$, and stored at $-80^{\circ} \mathrm{C}$ until use.

\section{Synthesis of cDNA for TBSV Egh}

First-strand cDNA was synthesized using Moloney Murine Leukemia Virus reverse transcriptase (Fermentas,USA) and its buffer (5×) $\left[50 \mathrm{mM}\right.$ Tris- $\mathrm{HCl}\left(\mathrm{pH} 8.3\right.$ at $\left.25^{\circ} \mathrm{C}\right), 250 \mathrm{mM} \mathrm{KCl}, 20 \mathrm{mM} \mathrm{MgCl}$ and $50 \mathrm{mM}$ DTT], $5 \mu$ of RNA was added to $(10 \mu \mathrm{l}(5 \times)$ RT-Buffer $), 2$ $\mu \mathrm{l}(10 \mathrm{mM}) \mathrm{dNTPs}, 5 \mu \mathrm{l}(20 \mathrm{pmol})$ concentrations of reverse TBSV full length primer TBSV(F): 5 '-ACG GGG GAT GAG CAA CTG G-3', 1 $\mu \mathrm{l}(200 \mathrm{u} / \mu \mathrm{l})$ of RT-enzyme, $27 \mu \mathrm{l} \mathrm{H}_{2} \mathrm{O}$. The mixture was incubated at $37^{\circ} \mathrm{C}$ for $60 \mathrm{~min}$, then at $70^{\circ} \mathrm{C}$ for $10 \mathrm{~min}$ [20].

Polymerase chain reaction (PCR) for second strand synthesis and amplification of cDNAs of the P42 coat protein (CP), P22 movement protein (MP), and $\mathrm{P} 33$ replication protein (RP) genes of TBSV Egh

PCR reaction was performed in a total volume of $50 \mu \mathrm{l}$, containing $5 \mu \mathrm{l}$ of $(10 \times)$ Taq DNA polymerase Buffer (Fermentas,USA) (100 mMTris- $\mathrm{HCl} \mathrm{pH} 8.8$ at $\left.25^{\circ} \mathrm{C}, 500 \mathrm{mM} \mathrm{KCl}\right), 1 \mu \mathrm{l} \mathrm{Taq}$-DNA Polymerase $(5 \mathrm{u} / \mu \mathrm{l})(1 \mathrm{~min} / \mathrm{kb})\left(\right.$ Fermentas,USA), $3 \mu \mathrm{MgCl}_{2}(25 \mathrm{mM}), 2 \mu \mathrm{l}(10$ $\mathrm{mM}) \mathrm{dNTP}$ mixture, $2 \mu \mathrm{l}$ from each primer $(20 \mathrm{Pmol} / \mu \mathrm{l}), 2 \mu \mathrm{l}$ from forward TBSV primer TBSV(F): 5 `-ACG GGG GAT GAG CAA CTG G-3' (20 Pmol) concentration, $2 \mu \mathrm{l}$ from reverse TBSV primer TBSVR: 5 `-ACT CGG ACT TTC GTC AGG A-3` (20 Pmol) concentration, $2 \mu \mathrm{l}$ from TBSV P33-131(F):5'-GGG GGA TAA ATT GTA ACT TC-3' (20 pmol) concentration, $2 \mu \mathrm{l}$ from TBSV P33-3051(R): 5'-GYT GTA ACA AAT TGC CGA C-3' (20 Pmol) concentration, and $2 \mu$ from TBSV P22-3856 (F): 5'-ATG GAT ACT GAA TAC GAA CAA G-3', $2 \mu$ from
TBSV P22-4552 (R):5'-TTC CAT ATC TCC ATC CCC-3' (20 Pmol) concentration, $2 \mu \mathrm{l}$ of TBSV genomic cDNA, and complete the total volume by add $33 \mu \mathrm{H}_{2} \mathrm{O}$ to a total of $50 \mu \mathrm{l}$.

The reaction mixture was subjected to amplification as follow: Denaturation of DNA template at $95^{\circ} \mathrm{C}$ for $2 \mathrm{~min}$, followed by 35 cycles of amplification with denaturation at $95^{\circ} \mathrm{C}$ for $2 \mathrm{~min}$, annealing at $60^{\circ} \mathrm{C}$ in case of $\mathrm{CP}$, for $\mathrm{P} 22$ was $61^{\circ} \mathrm{C}$ and for $\mathrm{P} 33$ was $55^{\circ} \mathrm{C}$ for 45 sec, and extension at $72^{\circ} \mathrm{C}$ for $3 \mathrm{~min}$ and ending with extension at $72^{\circ} \mathrm{C}$ for $10 \mathrm{~min}$. The PCR system (Gene Amp 9700 thermocycler, Applied Biosystem (ABI), USA) was used for performing PCR amplification. The PCR product was run on $1 \%$ agarose gel, electrophoresis in TBE and visualized under UV illumination.

\section{Purification of the PCR-amplified P42, P22 and P33 DNAs of TBSV Egh}

Purification was performed according to manufacturer's instructions using Ez Way Gel Extraction Kit (KOMA BIOTECH INC., biotechnology, USA). Purified PCR product was analyzed on $1 \%$ agarose gel in $1 \times$ TBE buffer, stained with ethidium bromide solution $(0.5 \mu \mathrm{g} /$ $\mathrm{ml}$ ) for $10 \mathrm{~min}$, visualized on an ultraviolet transilluminator (UVP) (M-20, upland, USA) and photographed using gel documentation system (Alpha-ChemImager, USA).

\section{Cloning of P42, P22 and P33 genes from TBSV Egh isolate}

Cloning vector: The purified PCR product of each gene was separately cloned in the vector (PCR 2.1-TOPO, Invitrogen, USA). The vector contain flori: origin of Replication, MCS: multiple cloning site, T7 Promotor, AMP: Ampicillin resistance, Kanamycin resistance and LacZ gene which provides $\alpha$-complementation for blue/white color selection of recombinant plasmids (Invitrogen, USA).

Transformation of each gene of TBSV Egh in E. coli competent cells: The cloning procedure was carried out according to the manufacturer's instructions, using TOPO TA Cloning Kit (Invitrogen, USA) [21].

Competent bacteria: $20 \mu \mathrm{l}$ of inoculated overnight on an incubator shaker at $37^{\circ} \mathrm{C} / 180 \mathrm{rpm}$ bacteria $E$. coli $\mathrm{DH} 5 \mathrm{a}$ (Invitrogen) were cultured in $10 \mathrm{ml}$ of $\mathrm{LB}$ media at $37^{\circ} \mathrm{C}$ for $3.5 \mathrm{~h}$. After centrifugation for $5 \mathrm{~min}$ at $6000 \mathrm{rpm}$, the pellet was re suspended slightly with $4 \mathrm{ml} \mathrm{CaCl}$ solution and put on ice for $20 \mathrm{~min}$. The mixture was then centrifuged at $6000 \mathrm{rpm}$ for $5 \mathrm{~min}$ and the pellet was re suspended again with $600 \mu \mathrm{l}$ of $1 \mathrm{M} \mathrm{CaCl}_{2}$ solution. $100 \mu \mathrm{l}$ of competent cells were used for transformation.

Transformation of $\boldsymbol{E}$. coli competent cell: The cloning procedure was carried out according to the manufacturer's instructions, using TOPO TA Cloning Kit (Invitrogen, USA) as described before.

Screening of transformed cells: Detection of recombinants was by using the blue/white colony screening technique. Each of the white and blue colonies were taken separately and cultured overnight in LB medium (10 g Tryptone, $5 \mathrm{~g}$ Yeast Extract, $5 \mathrm{~g} \mathrm{NaCl} / 1 \mathrm{~L}$ ) containing $100 \mu \mathrm{g} / \mathrm{ml}$ ampicillin at $37^{\circ} \mathrm{C}$.

Isolation of plasmid DNA from transformants (Plasmid miniprep): Plasmid DNA was isolated using the small-scale preparation of plasmid DNA by the alkaline lysis method. $1.5 \mathrm{ml}$ of the culture in a microfuge tube was centrifuged at $14,000 \mathrm{rpm}$ for $1 \mathrm{~min}$ at $4^{\circ} \mathrm{C}$ in the microfuge (biofuge 15-D-37520 osterode, Heraeus instruments Co., Germany). The remainder of the culture was stored at $4^{\circ} \mathrm{C}$, the medium was removed by aspiration to dry the pellet. Bacterial pellets were 
resuspended in $100 \mu \mathrm{l}$ of ice-cold solution I ( $50 \mathrm{mM}$ glucose, $25 \mathrm{mM}$ Tris. $\mathrm{HCl} \mathrm{pH}$ 8.0, $10 \mathrm{mM}$ EDTA pH 8.0) and vortexed vigorously. 200 $\mu \mathrm{l}$ of freshly prepared solution II $(0.2 \mathrm{~N} \mathrm{NaOH}, 1 \%$ SDS $)$ were added, and then the contents mixed by inverting the tube rapidly five times. The tubes were stored on ice for $5 \mathrm{~min} .150 \mu \mathrm{l}$ of ice-cold solution III ( $5 \mathrm{M}$ potassium acetate $60 \mathrm{ml}$, glacial acetic acid $11.5 \mathrm{ml}, \mathrm{H}_{2} \mathrm{O} 28.5 \mathrm{ml}$ ) were added to the mixture, and the tubes were vortexed gently in an inverted position for $1 \mathrm{~min}$ to disperse solution III through the viscous bacterial lysate. The tubes were stored on ice for 3-5 min, followed by centrifugation at $14,000 \mathrm{rpm}$ for $5 \mathrm{~min}$ at $4^{\circ} \mathrm{C}$, and the supernatants transferred to fresh tubes. Equal volumes of phenol: chloroform (1:1), were added and mixed by vortex, then centrifuged at $14,000 \mathrm{rpm}$ for $2 \mathrm{~min}$ at $4^{\circ} \mathrm{C}$ and the supernatant transferred to clean tubes. Double stranded DNA was precipitated with 2 volumes of absolute ethanol at room temperature. After centrifugation at $14,000 \mathrm{rpm}$ for $5 \mathrm{~min}$ at $4^{\circ} \mathrm{C}$, the pellets of double-strand DNA were rinsed with $1 \mathrm{ml}$ of $70 \%$ ethanol at $4^{\circ} \mathrm{C}$, and the pellets of nucleic acid allowed drying in air for $10 \mathrm{~min}$, redissolved in $50 \mu \mathrm{l}$ of TE buffer and the plasmids were stored frozen at $-20^{\circ} \mathrm{C}$ until use [20]. Small aliquots were analyzed on $1 \%$ agarose gel in $1 \times$ TBE buffer, stained with ethidium bromide solution $(0.5 \mu \mathrm{g} /$ $\mathrm{ml}$ ) for $10 \mathrm{~min}$. Plasmids carrying the insert were identified by their larger size on the agarose gel. The gel was visualized on an ultraviolet transilluminator (UVP) (M-20, upland, USA) and photographed using gel documentation system (Alpha- ChemImager, USA).

PCR for the identification of the plasmids carrying CP, MP and RP genes: Confirmation of cloning of CP gene of Egh TBSV isolate insert into the PCR 2.1-TOPO vector was performed as follow; PCR reaction was performed in a total volume of $50 \mu \mathrm{l}$, containing $5 \mu \mathrm{l}$ of $(10 \times)$ Taq DNA polymerase buffer (Fermentas, USA), $1 \mu \mathrm{l}$ Taq-DNA polymerase $(5 \mathrm{u} / \mu \mathrm{l})(1 \mathrm{~min} / \mathrm{kb})\left(\right.$ Fermentas, USA), $3 \mu \mathrm{lgCl}_{2}(25 \mathrm{mM})$, $2 \mu \mathrm{l}(10 \mathrm{mM}) \mathrm{dNTP}$ mixture, $2 \mu \mathrm{l}$ from each primer $(20 \mathrm{Pmol} / \mu \mathrm{l})$, forward TBSV full length primer TBSV(F): 5 ' -ACG GGG GAT GAG CAA CTG G-3' (20 Pmol) concentration, and $2 \mu \mathrm{l}$ from reverse TBSV full length primer TBSVR: 5 '-ACT CGG ACT TTO GTC AGG A-3` (20 Pmol) concentration, $2 \mu \mathrm{l}$ of the plasmid mini prep product, and complete the total volume by add $33 \mu \mathrm{l} \mathrm{H}_{2} \mathrm{O}$ to a total of $50 \mu \mathrm{l}$.

The reaction mixture was subjected to amplification. Small aliquots from the PCR product and pUC19 supplied by invitrogen TA cloning kit were used as control. DNA samples were analyzed on $1 \%$ agarose gel in $1 \times$ TBE buffer, stained with ethidium bromide solution $(0.5 \mu \mathrm{g} /$ $\mathrm{ml}$ ) for $10 \mathrm{~min}$, visualized on an ultraviolet transilluminator (UVP) (M-20, upland, USA) and photographed using gel documentation system (Alpha-ChemImager, USA).

Sequencing of each of TBSV Egh genes: Sequence of CP, MP and RP genes of TBSV Egh was carried out in the Eufrofins MWG operon lab, Anzinger Str.7a,85560 Ebersberg, GERMANY by using the forward primer CP F with the purified PCR product of CP ER.

Comparison of TBSV Egh genes with other known genes in different TBSV strains: Computer-based sequence comparison of each of CP, MP and RP genes CDNA sequence with other in different known TBSV reported strains was carried out by sequence alignment by the use of Clustal W (1.82) software (http://www2.ebi.ac.uk/ clustalW [21,22].

Phylogenetic tree comparison: Phylogenetic tree was generated using MEGA3 [23] from Clustal W alignments. This program allows performing multiple alignments of DNA or protein sequence.

Computer-based translation of each of CP, MP and RP partial sequences: Sequence of each gene was translated to the amino acid sequence, and then the protein statistics and amino acid distribution were performed.

Measurement of chlorophylls and carotenoids: Leaf pigments were analyzed as described in ref. [24]. Briefly, weighed two discs $(1.0 \mathrm{~cm}$ in diameter) from the first leaf, were ground with a mortar and pestle in $5-8 \mathrm{ml}$ of acetone $(80 \%, \mathrm{v} / \mathrm{v})$ in the presence of $\mathrm{CaCO}_{3}$ to prevent chlorophyll pheophytization. Homogenates were centrifuged for 3-4 min in glass tubes at $3000 \times g$. The resulting extracts were immediately assayed spectrophotometrically against pure $80 \%$ acetone as a blank by measuring the absorbance at 664,648 and $470 \mathrm{~nm}$. Specific absorption coefficients of Chl. $a$, Chl.b, and total Carotenoids reported by Lichtenthaler [25] were used. The pigment content was expressed on a dry weight basis (mg.g $\left.{ }^{-1} \mathrm{dw}\right)$.

\section{Carbohydrates Measurements}

\section{Extraction of soluble sugars}

Sugars were extracted according to the method of Riazi et al. [26]. A known dry weight $(0.3 \mathrm{~g})$ was submerged in $10 \mathrm{ml} 80 \%$ ethanol overnight with periodic shaking, then filtered through Whatman No. 1 filter paper and the filtrate was made up to a known volume with $80 \%$ ethanol.

\section{Determination of glucose}

Glucose contents were estimated using o-toluidine procedure of Feteris [27] as modified by Riazi et al. [26]. Absorbance was measured at $630 \mathrm{~nm}$ using Jenway 3510 spectrophotometer. Glucose contents were obtained by use of a calibration curve which was obtained using standard glucose solutions.

\section{Determination of sucrose}

Sucrose was determined by the anthrone method as described by Riazi et al. [26] with simple modifications. The first modification included using $70 \% \mathrm{v} / \mathrm{v}$ instead of $\mathrm{H}_{2} \mathrm{SO}_{4} \mathrm{w} / \mathrm{v}$ in preparation of anthrone reagent; this being made after found that $70 \% \mathrm{H}_{2} \mathrm{SO}_{4}(\mathrm{w} / \mathrm{v})$ would not dissolve anthrone. The second modification was made as several authors [28] recommended that aqueous solutions of sugars be used. Absorbance was read at $620 \mathrm{~nm}$ using a spectrophotometer.

\section{Determination of polysaccharides}

Polysaccharides content was estimated as described previously by Thayermanvan et al. [29].

\section{Statistic analysis}

The data are presented as the means of three replications. Assuming that, the conditions of $\mathrm{t}$-distribution of the difference between two means are satisfied. T-statistic was used to test the hypothesis that there is a significant difference between infected and healthy control plants. All statistically significant differences were tested at the $\alpha / 2=0.1$ level.

\section{Results}

\section{Estimation of the genomic size for the TBSV Egh}

RNA was extracted from TBSV Egh isolate and run on $1.2 \%$ formaldehyde agarose gel in $1 \times$ Formaldehyde running buffer. RNA separated in one band. The size of the RNA species with reference to the marker used was estimated to be approximately $\sim 4800 \mathrm{nt}$, as shown in Figure 1. 
Citation: Fattouh FA, Ali AS, Fathy RM (2015) Further Molecular Characterization and Effect on Host Photosynthetic Pigments and Carbohydrate Pools of an Egyptian Isolate of TBSV. J Plant Pathol Microb 6: 261. doi:10.4172/2157-7471.1000261

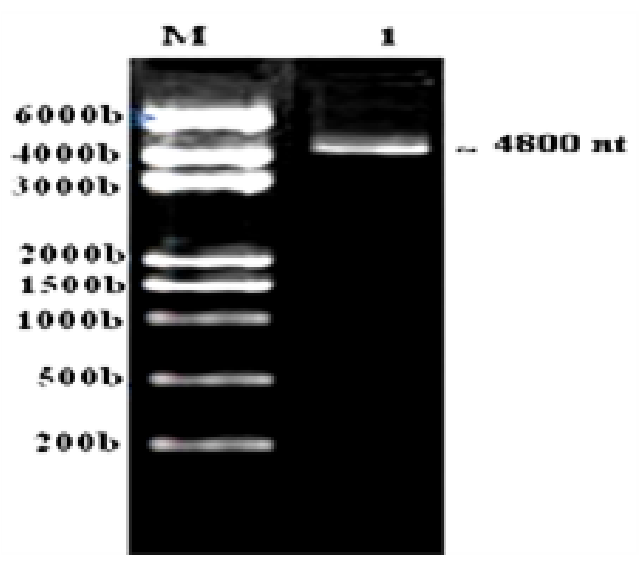

Figure 1: Electrophoretic mobility of TBSV Egh genomic RNA. Approximately $5 \mu \mathrm{l}$ of TBSV Egh isolate genomic RNA was run through $1.2 \%$ formaldehyde agarose gel in 1x Formaldehyde running buffer stained with ethidium bromide and photographed. Lane M: Molecular weight standard RiboRuler (200-6000 base) plus RNA ladder (Fermentase, USA); Lane1: TBSV Egh genomic RNA.

Polymerase chain reaction (PCR) for second strand synthesis and amplification of cDNAs of the CP (P42), MP (P22), and RP (P33) genes of TBSV Egh

The genome of TBSV Egh RNA was used as a template for the synthesis of a complementary first-strand (cDNA) by the use of a forward specific TBSV full length primer to be subsequently used for the synthesis of viral genomic corresponding DNAs. The synthesized cDNA was subsequently used with specific synthetic oligonucleotides designed from the full length genomic RNAs to act as primer for the amplification of cDNAs of specific genes $\mathrm{P} 42, \mathrm{P} 22, \mathrm{P} 33$. PCR products were purified from the PCR reaction mixture and separated by electrophoresis on $1 \%$ agarose gel in $1 \times$ TBE buffer. Results shown in Figure 2A-2C indicated the presence of PCR-amplified fragment of size $\sim 600 \mathrm{bp}$ for CP gene, PCR-amplified fragment of size $\sim 800 \mathrm{bp}$ for P33, and $\sim 900 \mathrm{bp}$ for $\mathrm{P} 22$ gene respectively.

\section{Purification of the PCR-amplified CP (P42), MP (P22), and} RP (P33) DNAs of TBSV Egh

Purification was performed according to manufacturer's instructions using Ez Way Gel Extraction Kit (KOMA BIOTECH INC., biotechnology, USA); Purified PCR product was analyzed on $1 \%$ agarose gel in $1 \times$ TBE buffer, stained with ethidium bromide solution $(0.5 \mu \mathrm{g} /$ $\mathrm{ml}$ ) for $10 \mathrm{~min}$, visualized on an ultraviolet transilluminator (UVP) (M20, Upland, USA) and photographed using gel documentation system (Alpha-ChemImager, USA. Results are shown in Figure 3, indicated the presence of PCR-amplified genes of size $\sim 900 \mathrm{bp}$ for P22, $\sim 800 \mathrm{bp}$ for P33, and $\sim 600 \mathrm{bp}$ for $\mathrm{CP}$ gene.

Cloning of the coat protein gene (CP), from TBSV Egh and transformation into $E$. coli competent cells

The TBSV Egh CP PCR products were cloned into the plasmid vector (pCR 2.1-TOPO). E. coli strain TOP10 $\mathrm{F}^{\prime}$ competent cells were transformed consecutively by incubation with pCR 2.1-TOPO plasmid carrying the CP gene insert which identified in the gene bank as (CP ER). E. coli transformed cells carrying the CP gene insert in the plasmid DNA were selected on LB plate supplemented with ampicillin $(100 \mu \mathrm{g} /$ $\mathrm{ml})$, X-gal and IPTG.

\section{Screening of the transformed cells}

Detection of recombinants was achieved by blue/white colony screening. The multiple cloning sites of the vector (pCR 2.1-TOPO) lies within the promoter of LacZ gene, which when expressed in the presence of inducer IPTG, produce the enzyme $\beta$-galactosidase. The reaction of this enzyme releases an indigo dye from the chromogenic substrate X-gal, resulting in the formation of a blue colony. Insert of a fragment within the MCS would result in the failure of LacZ gene expression, and the consequent formation of a white colony. White colonies were selected for further study.

\section{Isolation of plasmid DNA from transformants}

Selected transformant E. coli cells with plasmids harboring TBSV Egh insert gene were further used for the isolation of pCR 2.1-TOPO plasmid with insert. Liquid LB media supplemented with $100 \mu \mathrm{g} / \mathrm{ml}$ ampicillin was inoculated from transformant colonies with CP gene TBSV Egh clones. Each liquid culture was used for the purification of the CP gene recombinant plasmid; Figure 4 illustrates circular pCR 2.1TOPO plasmid in lane 1 and $\mathrm{CP}$ gene recombinant plasmid in lane 2. Change in the electrophoretic mobility on $1 \%$ agarose gel confirmed

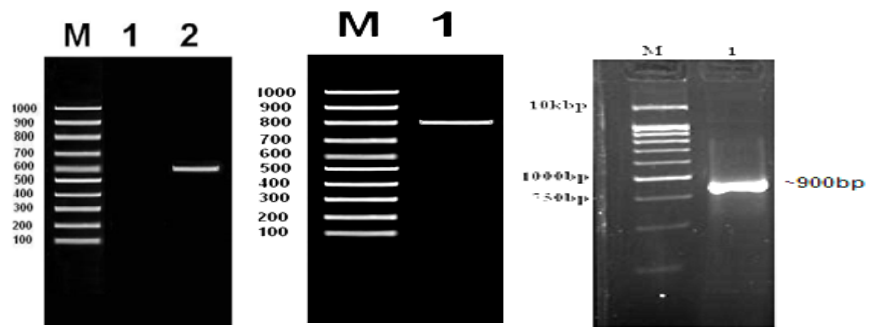

Figure 2: Electrophoretic mobility of P42 (CP), A; P33, B and P22, C genes of TBSV Egh purified PCR product amplified from cDNA using specific synthetic oligonucleotides primers. Approximately $5 \mu \mathrm{l}$ of P42 gene of TBSV Egh isolate was run through $1 \%$ agarose gel in 1 XTBE buffer and stained with ethidium bromide and photographed. A: Lane M: Fermentase Low Molecular Weight Standard (100bp to 1000bp); lane2: P42 of TBSV Egh. B: Lane M: Fermentase Molecular weight standard $(100 \mathrm{bp}-1 \mathrm{Kbp})$ DNA ladder Lane1: P33 gene of TBSV Egh. C: Lane M: Molecular Weight Standard 1Kb plus DNA ladder (Sib Enzyme); Lane1: P22 gene of TBSV Egh cDNAs.

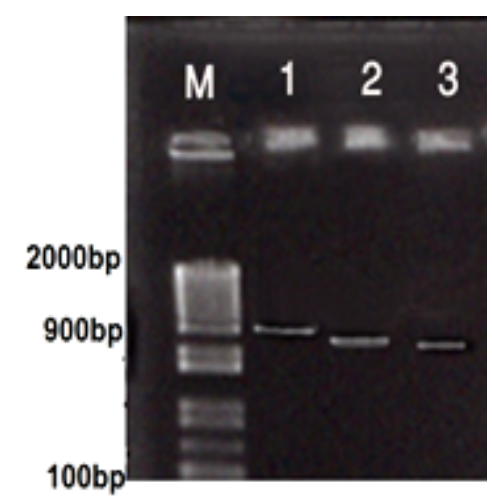

Figure 3: Electrophoretic mobility of TBSV Egh purified PCR products amplified from cDNA using specific synthetic oligonucleotides primers. Approximately $5 \mu$ of each TBSV Egh genes was run through $1 \%$ agarose gel in 1xTBE buffer stained with ethidium bromide and photographed. Lane M: Fermentase Molecular weight standard (100bp-2000bp) DNA ladder, Lane1: P22 gene, Lane2: P33 gene, Lane3: CP gene DNAs. 
Citation: Fattouh FA, Ali AS, Fathy RM (2015) Further Molecular Characterization and Effect on Host Photosynthetic Pigments and Carbohydrate Pools of an Egyptian Isolate of TBSV. J Plant Pathol Microb 6: 261. doi:10.4172/2157-7471.1000261

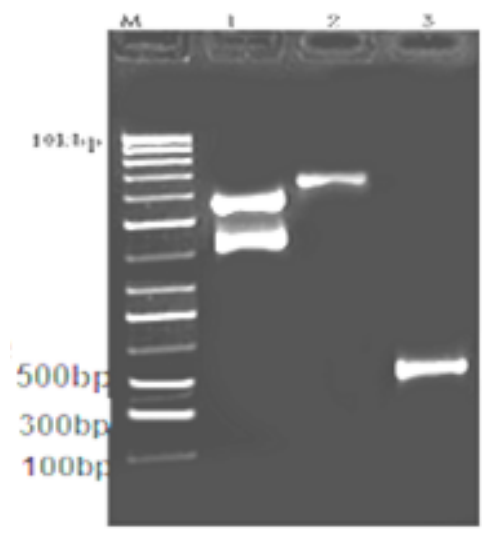

Figure 4: Electrophoretic mobility of plasmid DNA containing sequences of CP ER gene of TBSV Egh isolate from E.coli strain TOP10 F' transformants on $1 \%$ agarose gel stained with ethidium bromide. LaneM: Molecular weight standard $1 \mathrm{~Kb}$ plus DNA ladder (Sib Enzyme); Lane1: circular pCR 2.1TOPO plasmid vector; Lane2: CP ER recombinant plasmid; Lane3: PCR product of CP ER gene.

the presence of the insert in the recombinant plasmid due to change in size; the plasmid carrying insert had a larger size.

\section{Partial sequencing of TBSV Egh coat protein gene (CP)}

Partial sequencing of the cDNAs of CP of TBSV Egh was carried out in the Eufrofins MWG operon lab, Germany by using the forward primer P42 F with the purified PCR product of P42 ER. Recombinant plasmid cDNA carrying CP ER of TBSV Egh insert was sent for sequencing and the resulting nucleotide sequences are illustrated in Figure 5. The nucleotide sequence was later submitted to the NCBI nucleotide sequence database, Gene Bank. The nucleotide sequence of CP ER of TBSV Egh generated in this study was accepted and received accession numbers (HM439101).

\section{Comparison of CP gene of TBSV Egh with other known CP genes in different TBSV strains}

The NCBI nucleotide sequence database, Genbank, contains complete sequences of several TBSV strains. Multiple cDNA sequence alignment was carried out by using ClustalW (1.83), a multiple alignment program for DNA or proteins. A region at the 5 ' end of the genomic RNA corresponding to nucleotides 1 to 548 of the CP P42 ER gene of TBSV Egh isolate was sequenced and used for comparison between this isolats and the previously described TBSV strains, (http:// www2.ebi.ac.uk/clustalW [22]).

\section{Phylogenetic analysis illustrating evolutionary relationship between P42 coat protein gene (CP) of TBSV Egh and other TBSV strains}

Tomato Bushy Stunt Virus - Phylogenetic tree was generated using MEGA3 from ClustalW alignments. A region at the $5^{\prime}$ end of the genomic RNA corresponding to nucleotides 1 to 548 of the CP ER of TBSV Egh isolate was sequenced and used to determine the phylogenetic relationship of this isolate to previously described TBSV strains as shown in Figure 6. TBSV ER P42 occupied a distinct cluster compared to others previously reported isolates. This may be an indication that the Egyptian isolate may represent a different strain of TBSV. However, it shows a relatively closer relate dress to the AJ strain.

\section{Computer-based translation product of $\mathrm{P} 42$ coat protein gene (CP) of TBSV Egh sequence}

The partial sequence of CP ER gene of TBSV Egh (548bp), included $8.9 \mathrm{KDa}$ of TBSV coat protein gene. CP gene translation product is illustrated in Figure 7. Computer based translation of the partial sequence of TBSV Egh isolate P42 ER coat protein gave an $8.9 \mathrm{KDa}$ protein out of the $42 \mathrm{KDa}$. Analysis showed the isoelectric point to be 8.01 as shown in Table 1A. Amino acid distribution is as shown in Table $1 \mathrm{~B}$ and it indicates the highest count of the amino acid threonine (16) whereas glutamic acid, lysine and tryptophane were not detected in the sequence translated protein product.

\section{Cloning and sequencing of the movement protein gene (P22 MP), from TBSV Egh}

The P22 gene of TBSV Egh PCR products were cloned into the plasmid vector (pCR 2.1-TOPO). E. coli strain TOP10 F' competent cells were transformed consecutively by incubation with pCR 2.1TOPO plasmid carrying full length insert. E. coli transformed cells carrying the full length insert in the plasmid DNA were selected on

1 acgggggate agcaactgga ggtaccactt ctaccttcaa acttcaa gaaagtccga 61 gtacggggga tgagcaactg gecetggata cetcctggtg tctaggactg ccactgtatt 121 ttccgtgcta caggcacgtt tgtcatatcc gggacgtatc ggtgcctcac

181 ggcaacaaacg ttaggettgg ctggeggagt gaatgtcaat agtatcacag ttgtagataa

241 cataggtaca gacagtgcgt ttttcataaa ttgtactgtc tctaacctac catctgtggt

301 gacattcaca tctaccggta tcacatctge cacagtacat tgcgtgcgeg cgacacgaca

361 gaatgatgtt tctctaattt agtgtgtcct gcgagggget tcttgaacaa gaccagttca

421 tggatactga atacgaataaac gtcaataaac catggaacga gctatacaag gaaacgacgc

481 tagggaacaa gctaacagtg aacgttggga tggaggatca ggaggtacca cttctccett

541 caaacttc

Figure 5: Partial sequencing for the TBSV genomic CDNA of CP P42 of TBSV Egh, (548bp) NCBI Genbank accession number (HM439101).

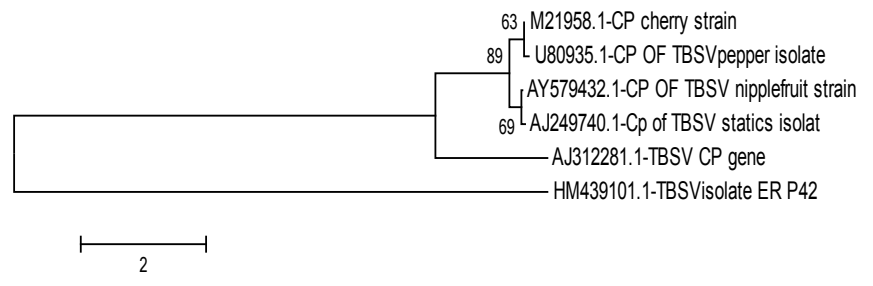

Figure 6: Phylogenetic tree generated using MEGA3 from ClustalW alignment for TBSV CP (548 bp) in comparison to sequences of other CP of TBSV strains.

"MTFRATGTFVISGTYRCLTATTLGLAGGVNVNSITVVDNIGTDSAFFINCTVSNLPSVVT FTSTGITSAT VHCVRATRQNDVSLI"

Figure 7: Translation product of P42 (CP) gene of TBSV Egh isolate partial sequence encoding for $8.9 \mathrm{KDa}$ proteins.

\begin{tabular}{|c|c|}
\hline Sequence type & Protein \\
\hline Isoelectric point & 8.01 \\
\hline Weight & $8.9 \mathrm{KDa}$ \\
\hline Description & P42 ER gene of TBSV Egyptian isolate \\
\hline Organism & TBSV Egh \\
\hline Length & 85 \\
\hline
\end{tabular}

Table 1A: Protein sequence information for P42 CP gene of $8.9 \mathrm{KDa}$ protein. 
Citation: Fattouh FA, Ali AS, Fathy RM (2015) Further Molecular Characterization and Effect on Host Photosynthetic Pigments and Carbohydrate Pools of an Egyptian Isolate of TBSV. J Plant Pathol Microb 6: 261. doi:10.4172/2157-7471.1000261

\begin{tabular}{|c|c|c|}
\hline Amino acids & Count & Frequency \\
\hline Tyrosine (Y) & 1 & 0.012 \\
\hline Tryptophane (W) & 0 & 0 \\
\hline Valine (V) & 11 & 0.129 \\
\hline Threonine $(T)$ & 16 & 0.188 \\
\hline Serine (S) & 8 & 0.094 \\
\hline Arginine $(\mathrm{R})$ & 4 & 0.047 \\
\hline Glutamine (Q) & 1 & 0.012 \\
\hline Proline $(\mathrm{P})$ & 1 & 0.012 \\
\hline Asparagine $(\mathrm{N})$ & 6 & 0.076 \\
\hline Methionine (M) & 1 & 0.012 \\
\hline Leucine (L) & 5 & 0.058 \\
\hline Lysine (K) & 0 & 0 \\
\hline Isoleucine (I) & 6 & 0.076 \\
\hline Histidine $(\mathrm{H})$ & 1 & 0.012 \\
\hline Glycine (G) & 7 & 0.082 \\
\hline Phenylalanine $(F)$ & 5 & 0.058 \\
\hline Glutamic acid (E) & 0 & 0 \\
\hline Asparatic (D) & 3 & 0.035 \\
\hline Cysteine (C) & 3 & 0.035 \\
\hline Alanine (A) & 6 & 0.076 \\
\hline
\end{tabular}

Egyptian isolate may represent a different strain of TBSV. However, it shows a relatively closer relate dress to the pepper strain as shown in the phylogenetic tree.

Computer-based translation product of P22 movement protein gene of TBSV Egh sequences

The partial sequence of P22 ERM gene of TBSV Egh (697bp), include the complete open reading frames of P22 gene encoding for TBSV 21.6 KDa protein. P22 gene translation product is illustrated in Figure 11, sequence and amino acid distribution are presented in Tables $2 \mathrm{~A}$ and $2 \mathrm{~B}$ respectively. Computer based translation of the partial sequence of TBSV Egh isolate gave a 21.6 KDa protein product out of the total $22 \mathrm{KDa}$. Analysis showed the isoelectric point to be 9.72 as shown in Table 2A. Amino acid distribution is as shown in Table 2B

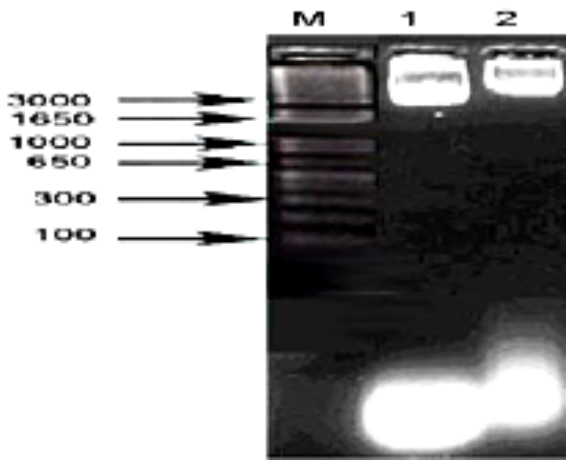

LB plate supplemented with ampicillin $(100 \mu \mathrm{g} / \mathrm{ml}), \mathrm{X}$-gal and IPTG. White colonies were selected for further study.

Selected transformant E. coli cells with plasmids harboring P22 gene of TBSV Egh identified in the gene bank as (P22) inserts were further used for the isolation of pCR 2.1-TOPO Plasmid with insert. Liquid LB media supplemented with $100 \mu \mathrm{g} / \mathrm{ml}$ ampicillin was inoculated from transformant colonies with P22 gene of TBSV Egh clones. Each liquid culture was used for the purification of the P22 Egh recombinant plasmid. Figure 8, illustrates circular pCR 2.1-TOPO plasmid in lane 1 and full length recombinant plasmid in lane 2 . Change in the electrophoretic mobility on $1 \%$ agarose gel confirmed the presence of the insert in the recombinant plasmid due to change in size; the plasmid carrying insert had a larger size.

\section{Partial sequencing of TBSV Egh movement protein gene (MP ERM)}

Partial sequencing of the cDNAs of P22 ERM (movement protein) of TBSV Egh was carried out in the Eufrofins MWG operon lab, GERMANY by using the forward primer P22 F with the purified PCR product of P22 ERM. Recombinant plasmid cDNA carrying P22 ERM of TBSV Egh insert was sent for sequencing and the resulting nucleotide sequences are illustrated in Figure 9. The nucleotide sequence was later submitted to the NCBI nucleotide sequence database, GenBank. The nucleotide sequence of P22 ERM of TBSV Egh generated in this study was accepted and received accession numbers (JX418297).

\section{Phylogenetic analysis illustrating evolutionary relationship between P22 movement protein gene of TBSV Egh and other TBSV strains}

TBSV ERM P22 - Phylogenetic tree was generated using MEGA3 from ClustalW alignments, a region at the 5 ' end of the genomic RNA corresponding to nucleotides 1 to 697 of the P22 EM gene of TBSV Egh was sequenced and used to determine the phylogenetic relationship of this isolate to previously described TBSV P22 genes as shown in Figure 10. TBSV ERM P22 occupied a distinct cluster compared to others previously reported isolates. This may be an indication that the

1 ttccatatct ccatccecta ggcgaccaaa cctagtgcgg agccegagtc gactcgtcat 61 cctaacatcc agaacccaac aagagtaacc tgtatgctat gecagattta cactcatctc 121 cacaaactca gactgaagag tctgtcttac tcgctttctt tttcgaaggt ttcagtacct 181 tcagggcatc ctcttgatac attactttcc acttcgattg gggcaagctg tagcagttct 241 tgettagacc gaattgccat ctcacagaga tgctgaagag ttcgcgaccc tccagaaacg 301 gtgatactaa ctcctcgaaa ccgaatacta taggtacatc cgatctggtc gaaaccgaaa 361 aatcgagatg ctgcatagtt aaccgaatct cccgtccaag atccaaggac tctgtgcagt 421 gaagcttccg tcetgtcgta tctgagatat ctcttaaata caactttccc gaaaccccag 481 ctttccttga aaccaagggg attatcttga ttcgaattcg tctcatcgtt atgtagccgc 541 cactcagtcc aactcggact ttcgtcagga agtttgaagg gagaagtggt acctcetgat 601 cctccatccc aacgttcact gttagcttgt tccetagegt cgtttccttg tatagctcgt 661 tccatggttt attgacttgt tcgtattcag tatccat

Figure 9: Partial sequencing for the TBSV genomic cDNA of P22 of TBSV Egh, (697bp) NCBI Gen bank accession number (JX418297)

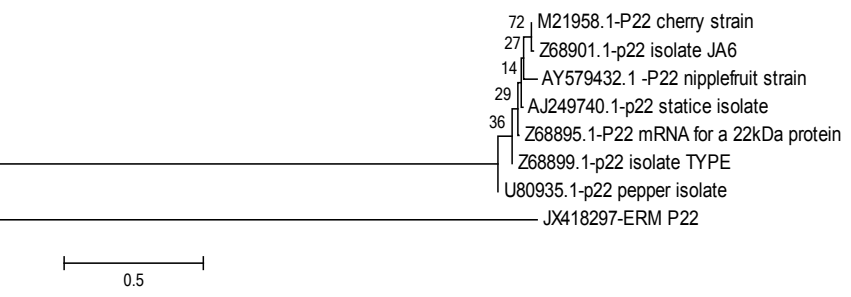

Figure 10: Phylogenetic tree generated using MEGA3 from ClustalW alignment for TBSV P22 (697 bp) in comparison to sequences of other P22 of TBSV strains. 
Citation: Fattouh FA, Ali AS, Fathy RM (2015) Further Molecular Characterization and Effect on Host Photosynthetic Pigments and Carbohydrate Pools of an Egyptian Isolate of TBSV. J Plant Pathol Microb 6: 261. doi:10.4172/2157-7471.1000261

Page 7 of 10

"MDTEYEQVNKPWNELYKETTLGNKLTVNVGMEDQEVPLLPSNFLTKVRVGLSGGYIT MRRIRIKIIPLVSRKAGVSGKLYLRDISDTTGRKLHCTESLDLGRIRL

TMQHLDFSVSTRSDVPIVFGFEELVSPFLEGRELFSISVRWQFGLSKNCYSLPQ SKWKVMYQEDALKVLKPSKKKASKTDSSV"

Figure 11: Translation product of P22 gene of TBSV Egh partial sequence encoding for $21.8 \mathrm{KDa}$ proteins.

\begin{tabular}{|c|c|}
\hline Sequence type & 9.72 \\
\hline Isoelectric point & $21.6 \mathrm{KDa}$ \\
\hline Weight & P22 EM gene of TBSV Egyptian isolate \\
\hline Description & TBSV Egh \\
\hline Organism & 189 \\
\hline Length & Protein \\
\hline
\end{tabular}

Table 2A: Protein sequence information for P22 gene of $21.6 \mathrm{KDa}$ protein.

\begin{tabular}{|c|c|c|}
\hline Amino acids & Count & Frequency \\
\hline Tryptophane (W) & 6 & 0.032 \\
\hline Valine (V) & 3 & 0.016 \\
\hline Threonine (T) & 16 & 0.085 \\
\hline Serine (S) & 12 & 0.063 \\
\hline Arginine (R) & 19 & 0.101 \\
\hline Glutamine (Q) & 12 & 0.063 \\
\hline Proline $(P)$ & 6 & 0.032 \\
\hline Asparagine $(\mathrm{N})$ & 8 & 0.042 \\
\hline Methionine (M) & 6 & 0.032 \\
\hline Leucine (L) & 5 & 0.026 \\
\hline Lysine (K) & 22 & 0.116 \\
\hline Isoleucine (I) & 17 & 0.089 \\
\hline Histidine $(\mathrm{H})$ & 9 & 0.047 \\
\hline Glycine $(G)$ & 2 & 0.011 \\
\hline Phenylalanine (F) & 12 & 0.063 \\
\hline Glutamic acid $(E)$ & 7 & 0.037 \\
\hline Asparatic (D) & 13 & 0.068 \\
\hline Cysteine (C) & 9 & 0.047 \\
\hline \multirow[t]{2}{*}{ Alanine $(\mathrm{A})$} & 2 & 0.011 \\
\hline & 3 & 0.016 \\
\hline
\end{tabular}

Table 2B: Amino acid distribution for $\mathrm{P} 22$ gene of $21.6 \mathrm{KDa}$ protein.

and it indicates the highest count for the amino acid leucine (22) and all amino acids were present in this protein product.

\section{Effect of TBSVEgh infection on photosynthetic pigments}

Factors affecting light absorption of host leaves such as chlorophylls as well as carotenoids contents of healthy control and TBSV Eghinfected L. esculentum and C. pepo leaves were measured as shown in Table 3. Results indicated that, in case of L. esculentum and C. pepo TBSV Egh-infected leaves occur losses in chlorophylls content in both hosts. TBSV Egh-infection induced significant $(\alpha / 2=0.1)$ decreases in chlorophyll a, chlorophyll $\mathrm{b}$ and subsequently in the total chlorophylls contents of $L$. esculentum and $C$. pepo leaves compared to healthy control plants. In contrast, TBSV-Egh infected leaves of L. esculentum and $C$. pepo showed increase in chlorophyll a/chlorophyll b ratio, when compared to healthy control plants. Carotenoids showed nonsignificant variable changes $(\alpha / 2=0.1)$ in leaves of both TBSV Eghinfected hosts. Carotenoids content was increased from (0.992) to (1.147) $\mathrm{mg} . \mathrm{g}^{-1} \mathrm{dw}$ in case of $L$. esculentum leaves, and reduced from (1.907) to (1.455) mg. $\mathrm{g}^{-1} \mathrm{dw}$ in case of C. pepo leaves.

\section{Effect of TBSVEgh-infection on carbohydrate pools}

The results in Figure 12A-12C, showed variable changes in glucose, sucrose and polysaccharides content of TBSV Egh-infected $L$. esculentum and $C$. pepo leaves when compared with healthy control plants. Glucose and polysaccharides content of TBSV Egh-infected $L$. esculentum leaves displayed a significant $(\alpha / 2=0.1)$ decreases as they

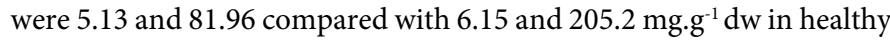
control plants, respectively. On the other hand, sucrose content of the same plants increased significantly from 11.53 in healthy control plant to $12.36 \mathrm{mg} . \mathrm{g}^{-1} \mathrm{dw}$ in infected plants. Glucose content of TBSVinfected $C$ pepo plants showed no significant difference $(\alpha / 2=0.1)$ from healthy control leaves whereas, it reduced from 6.59 to $6.47 \mathrm{mg} . \mathrm{g}^{-1} \mathrm{dw}$. On the other hand, sucrose and polysaccharides contents of TBSV Eghinfected $C$ pepo leaves showed a significant $(\alpha / 2=0.1)$ increase (from

\begin{tabular}{|c|c|c|c|}
\hline Pigments (mg. $\mathrm{g}^{-1} \mathrm{dw}$ ) & Health leaves & TBSVEgh infected leaves & $\mathbf{t}$ \\
\hline \multicolumn{4}{|l|}{ L. esculentum } \\
\hline Chl. a & $8.10 \pm 0.50$ & $5.21^{*} \pm 1.02$ & 2.54 \\
\hline Chl. b & $5.10 \pm 0.15$ & $3.00^{*} \pm 0.73$ & 2.811 \\
\hline Chl a + Chl. b & $13.19 \pm 0.35$ & $8.21^{*} \pm 1.75$ & 2.795 \\
\hline Chl. a/Chl. b & $1.60 \pm 0.14$ & $1.79 \pm 0.12$ & -1 \\
\hline Car. & $0.99 \pm 0.15$ & $1.20 \pm 0.12$ & -1.01 \\
\hline \multicolumn{4}{|l|}{ C. pepo } \\
\hline Chl. a & $17.17 \pm 0.78$ & $10.41^{*} \pm 2.4$ & 2.679 \\
\hline Chl.b & $10.15 \pm 0.02$ & $5.95^{*} \pm 1.28$ & 3.277 \\
\hline Chl.a + Chl.b & $27.32 \pm 0.78$ & 16. $36^{*} \pm 3.68$ & 2.913 \\
\hline Chl.a/Chl.b & $1.691 \pm 0.08$ & $1.74^{*} \pm 0.028$ & -5.5 \\
\hline Car & $1.907 \pm 0.08$ & $1.46^{*} \pm 0.39$ & 2.306 \\
\hline
\end{tabular}

*show significant differences between infected and health leaves $(\alpha / 2=0.1)$.

Table 3: Changes in photosynthetic pigments content in TBSV Egh-infected leaves of Lycopersicon esculentum and Cucurbita pepo. Values are means \pm standard errors of three replicates.

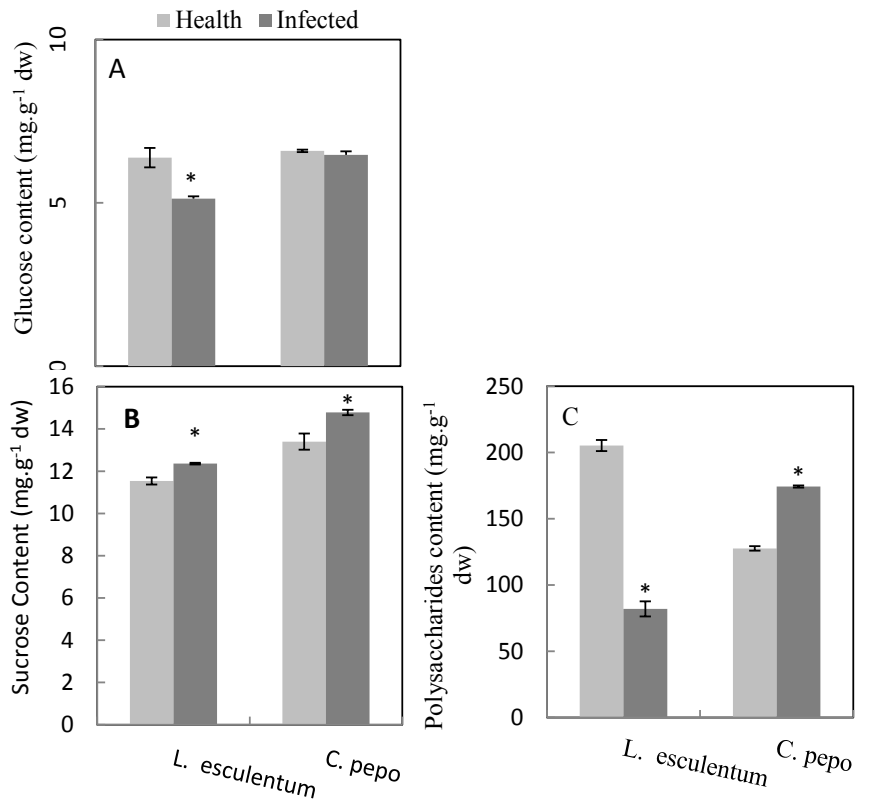

Figure 12: Changes in the carbohydrate pools (glucose, A; sucrose, B and polysaccharides, C) in TBSV Egh-infected leaves of $L$. esculentum and $C$. pepo. Bars are the standard error of the mean. Asterisks show significant differences between infected and health leaves $(\alpha / 2=0.1)$. 
13.40 to 14.78 and from 127.61 to $174.27 \mathrm{mg}^{-1} \mathrm{dw}$ ) in relative to healthy control leaves (Figure 12A-12C).

\section{Discussion}

The complete genome of TBSV Egh isolate was found to be approximately $4800 \mathrm{nt}$ in length, which is in agreement with previous reports [30,31]. The TBSV genome organization reveals 5 ORFs encoding 5 viral proteins [32]. Partial sequences are available for several tombusviruses isolate [33], which has been useful in classification and strain differentiation of tombusvirus isolates. We designed primers from the available sequence data in the GenBank for cloning and sequencing of the genome of the Egyptian isolate TBSV Egh. Partial sequencing of $\sim 548 \mathrm{bp}$ of the TBSV Egh of P42 coat protein gene (CP P42 ER) was performed. The nucleotide sequence when submitted to the NCBI nucleotide sequence database, GenBank received an accession number of HM439101. The coat protein CP (P42) is not translated from TBSV genomic RNA but rather from subgenomic RNA1 (sg RNA1). The two TBSV subgenomic mRNAs lack 5'-cap structures yet they are translated efficiently in vitro and in vivo. The start codon for translation of sgRNA1 is in a favourable context to yield high levels of $\mathrm{CP}$ [7]. Time-course experiments at an early time-point after infection suggest that transcription of sgRNA1, and subsequent accumulation of $\mathrm{CP}$, is relatively late events [34]. This is in agreement with a model that virion assembly in infected cells occurs after the infection has already progressed to neighboring cells.

The precise biochemical mechanisms of replication and transcription of plus-sense RNA plant viruses remain to be defined, but much has been learned in recent years [35]. Knowledge concerning viral RNA elements and proteins involved in replication is becoming increasingly detailed $[36,37]$. The efficient systemic movement of most RNA plant viruses requires expression of the viral coat protein (CP) and the assembled virus particles in some cases [38]. TBSV belongs to a unique class of RNA viruses that do not require $\mathrm{CP}$ for systemic infection in certain hosts.

The taxonomy of the genus Tombusvirus has been based on serology and has resulted in unsatisfactory classification of isolates [39]. Within the TBSV species, two main clusters of field isolates represented by the strains TBSV-Ch and TBSV-BS3 were distinguished by phylogenetic analysis of sequence data. TBSV-type, the tomato isolates originally described in the 1930s and from which the BS3 strain was derived, the eggplant field isolate B2, and AMCV were placed as separate TBSV strains. This agrees with the results of the biological assays (in which TBSV-type behaved as TBSV- BS3-like isolates). The information reported here may aid in TBSV strain classification and also can serve in designing nucleic acid probes for strain-specific diagnosis of TBSV.

Partial sequencing of $\sim 697 \mathrm{bp}$ of the TBSV Egh P22 movement protein gene (MP P22 ERM) was performed using specific oligonucleotide primers. The nucleotide sequence when submitted to the NCBI nucleotide sequence database, GenBank was accepted and received an accession number JX418297. Accumulation of sgRNA2 is a relatively early event in TBSV infection [34]. P22 and P19 are known to be located in a nested form at the 3'-proximal end and translation of the nested P22 and P19 genes from sgRNA2 occurs via contextdependent ribosome leaky scanning $[7,8]$. The products of P22 and P19 tombusvirus genes contribute independently to pathogenicity [32]. The TBSV p22 and p19 gene products (P22 and P19), or their equivalents in other species, are involved in cell-to-cell movement and host-specific systemic spread, respectively and P19 also serves as a major symptom determinant [40]. The important features for this process are a relatively short untranslated leader sequence on sgRNA2, a suboptimal translation initiation context surrounding the AUG of P22, , and close proximity of the downstream AUG for P19 that is positioned in an optimal context for initiation of translation. Consequently, translation of P22 occurs inefficiently and ribosomes preferentially initiate translation at the AUG of P19, to result in an abundant and early accumulation of $\mathrm{P} 19$ [7]. This process leads to a dosage control of the ratio of $\mathrm{P} 22 / \mathrm{P} 19$ which is important for their biological activities during infection. The partial sequence of TBSV Egh P19 gene has been reported in an earlier study [1].

The classical symptoms of virus infected-plants represent an imbalance in photosynthetic pigments synthesis and defects in the structure and function of chloroplasts $[41,42]$. TBSV Egh-infection triggered a sharp decrease in a total chlorophylls content of L. esculentum and C. pepo plants to about $62 \%$ and $60 \%$ of the corresponding healthy control plants, respectively (Table 3 ). The chlorophyll a/b ratio increased non-significantly and interesting findings were the variable changes in carotenoids content of TBSV Egh-infected L. esculentum and C. pepo plant. Concurrent with the present findings S. nigrum-ObPV virus infection may have caused a significant alteration in thylakoid composition as it is evidenced from the increased chlorophyll $a / b$ ratio of leaves. This indicates that virus infection reduced the amount of light harvesting complexes $[43,44]$. Hence one can hypothesize that viral replication and nucleic acid synthesis may monopolize and cause high demands on energy in the form of ATP in infected cells, inducing alterations in the ratio chla/chlb and interfering with photochemical activity of infected leaves. The decrease in total chlorophylls content coupled with lower concentrations of carotenoids is resulted from the loss of defense mechanism of plants against oxidative stress cuased by virus infection [45]. In other case, increase in carotenoids content is an evidence to improve the antioxidative capacity of virus-infected plants [46].

Virus infection can cause comprehensive physiological changes in some plant hosts, such as altered water content of tissues and the synthesis and translocation of primary metabolites as increase in glucose, fructose and sucrose in virus infected plants $[47,48]$. In this study, TBSV Egh-infection induced a variable changes in carbohydrate pools of L. esculentum and C. pepo plants. Contradictory changes were obtained in case of polysaccharides content which decreased significantly in infected $L$. esculentum plants and increased significantly in infected C. pepo plants compared with healthy control plants. The increase in soluble sugars and the inhibition of starch accumulation and/or starch degradation may be due to the increased demand for soluble sugars (mainly glucose) required maintaining the high respiration rate in virus infected plants. CMV-infection induced higher starch hydrolase and lower ADP-Glc pyrophosphorylase activities which might be explained the increase in reducing sugars and a reduction in starch content [17]

In plant microbe interactions, sugars are essential to fuel the energy required for defenses and serve as signals for the regulation of defense genes [49]. The potential key roles of some sugars regarding plant immunity have recently led to the "sweet Immunity" and "sugarenhanced defense" concepts [50]. Regarding their roles in plant immunity, the question is to determine whether carbohydrates could be helpful in control- ling plant diseases in field conditions [51].

In conclusion, the similarity and the phylogenetic analyses of sequences shown in the results with others reported isolates; show that all belong to a single virus species. Within the TBSV species, phylogenetic analyses reveal the presence of two main clusters of field 
Citation: Fattouh FA, Ali AS, Fathy RM (2015) Further Molecular Characterization and Effect on Host Photosynthetic Pigments and Carbohydrate Pools of an Egyptian Isolate of TBSV. J Plant Pathol Microb 6: 261. doi:10.4172/2157-7471.1000261

isolates. All previously reported isolates e.g. nipplefruit, statice, pepper, cherry or other isolate are clustered together whereas the Egyptian TBSV Egh ERM P22 and ER P42 are present in a separate cluster this might indicate that our isolate could be a representative of a new strain of TBSV. The P42 gene ER seems closest in homology to the AJ isolate whereas, the P22 gene ERM seems more similar in sequence homology to the pepper isolate. Such studies could reveal evolutionary relationships between different isolates and is more recently attracting attention as a method of tracing the introduction of new isolates of virus into geographic regions away from the origin. This may assist in efforts to control spread of viral diseases. TBSV Egh-infection triggered a pronounced decrease in photosynthetic pigments: $\operatorname{chl} a, \operatorname{chl} b$ and total chlorophylls. This sure, would reflect a disturbance in photosynthetic apparatus and photosynthesis process. TBSV Egh-infection resulted in a significant increase in sucrose content in both tested host plants. Virus infection unexpectedly increases polysaccharides content in $C$. pepo plants.

\section{References}

1. Hafez el SE, Saber GA, Fattouh FA (2010) Tomato bushy stunt virus (TBSV) infecting Lycopersicon esculentum. Z Naturforsch C 65: 619-626.

2. Lommel SA, Martelli GP, Russo M (2000) Tombusviridae. Virus Taxonomy. Seventh Report of the International Committee on Taxonomy of Viruses pp. $791-825$

3. Reade R, Miller J, Robbins M, Xiang Y, Rochon D (2003) Molecular analysis of the cucumber leaf spot virus genome. Virus Res 91: 171-179.

4. Rubino L, Russo M (1997) Molecular analysis of the pothos latent virus genome. J Gen Virol 78: 1219-1226.

5. Chu M, Park JW, Scholthof HB (1999) Separate regions on the tomato bushy stunt virus p22 protein mediate cell-to-cell movement versus elicitation of effective resistance responses. Molecular Plant-Microbe Interaction 12: 285 292.

6. Qu F, Morris TJ (2002) Efficient infection of Nicotiana benthamiana by Tomato bushy stunt virus is facilitated by the coat protein and maintained by $\mathrm{p} 19$ through suppression of gene silencing. Mol Plant Microbe Interact 15: 193-202.

7. Scholthof HB, Desvoyes B, Kuecker J, Whitehead E (1999) Biological activity of two tombusvirus proteins translated from nested genes is influenced by dosage control via context-dependent leaky scanning. Molecular Plant-Microbe Interaction 12: 670-679.

8. Kozak M (2002) Pushing the limits of the scanning mechanism for initiation of translation. Gene 299: 1-34

9. Oster SK, Wu B, White KA (1998) Uncoupled expression of p33 and p92 permits amplification of tomato bushy stunt virus RNAs. J Virol 72: 5845-5851.

10. Rajendran KS, Nagy PD (2003) Characterization of the RNA-binding domains in the replicase proteins of tomato bushy stunt virus. J Virol 77: 9244-9258.

11. Panaviene Z, Baker JM, Nagy PD (2003) The overlapping RNA-binding domains of p33 and p92 replicase proteins are essential for tombusvirus replication. Virology 308: 191-205.

12. Rajendran KS, Nagy PD (2004) Interaction between the replicase proteins of Tomato bushy stunt virus in vitro and in vivo. Virology 326: 250-261.

13. Filella I, Serrano I, Serra J, Peñuelas J (1995) Evaluating wheat nitrogen status with canopy relfectance indices and discriminant analysis. Crop Science 35 $1400-1405$.

14. Moran JA, Mitchell AK, Goodmanson G, Stockburger KA (2000) Differentiation among effects of nitrogen fertilization treatments on conifer seedlings by foliar reflectance: a comparison of methods. Tree Physiol 20: 1113-1120.

15. Handford MG, Carr JP (2006) Plant metabolism associated with resistance and susceptibility. In Natural Resistance Mechanisms of Plants to Viruses, pp: 315340.

16. Loebenstein G, Akad F (2006) The local lesion response. In: Loebenstein G, Carr JP (eds.) Natural Resistance Mechanisms of Plants to Viruses, Dordrecht: Springer, pp. 99-124.

17. Tecsi L, Maule AJ, Smith AM, Leegood RC (1994) Complex, localized changes in $\mathrm{CO} 2$ assimilation and starch content associated with the susceptible interaction between cucumber mosaic virus and a cucurbit host. The Plant Journal 5: 837-47.

18. Wang D, Maule AJ (1995) Inhibition of host gene expression associated with plant virus replication. Science 267: 229-231.

19. Lůcas WJ, Wolf S (1993) Plasmodesmata: the intercellular organelles of green plants. Trends Cell Biol 3: 308-315

20. Sambrook J, Russel DW (2001) Molecular Cloning: a Laboratory Manual (3rdedn) Cold Spring Harbor, NY: Cold Spring Harbor Laboratory Press.

21. Werner R (2005) The development and production of biopharmeceuticals: technology and economic success factors. Bioprocess Int 6-15.

22. Thompson JD, Gibson TJ, Plewniak F, Jeanmougin F, Higgins DG (1997) The ClustalX windows interface: Flexible strategies for multiple sequence alignment aided by quality analysis tools. Nucleic Acids Research 24: 4876-4882.

23. Kumar S, Tamura K, Nei M (2004) MEGA3: Integrated software for Molecula Evolutionary Genetics Analysis and sequence alignment. Brief Bioinform 5 150-163.

24. Steele MR, Gitelson AA, Rundquist DC, Merzlyak MN (2009) Non-destructive estimation of anthocyanin content in grapevine leaves. American Journal Enology Viticulture 60: 87-92.

25. Lichtenthaler HK (1987) Chlorophyll and carotenoids: Pigments of photosynthetic biomembranes. Methods in Enzymol 148: 331-382.

26. Riazi A, Matsuda K, Arslan A (1985) Water-stress induced changes in concentrations of proline and other solutes in growing regions of young barley leaves. Journal of Experimental Botany 36: 1716-1725.

27. Feteris WA (1965) A serum glucose method without protein precipitation. Am J Med Technol 31: 17-21.

28. Buysse J, Merckx R (1993) An improved colorimetric method to quantify sugar content of plant tissue. Journal of Experimental Botany 44: 1627-1629.

29. Thayermanvan V, Sadasivam S (1984) Qual Plant Hum Nutr. Quoted from Biochemical Methods. Sadasivam S, Manicham A (eds.) (2ndedn) New Ag. Inter. Limit. Publ. New Delhi, India, 34: 253-257.

30. Brunt AA, Crabtree K, Dallwitz MJ, Gibbs AJ, Watson L, et al. (1996) Plant viruses online: Descriptions and lists from the VIDE database Version.

31. Kim MK, Kwak HR, Jeong SG, Ko SJ, Lee SH, et al.(2007) First Report on Tomato bushy stunt virus Infecting Tomato in Korea. Plant Pathology Journal 23: $143-150$

32. Russo M, Burgyan J, Martelli GP (1994) Molecular biology of tombusviridae. Adv Virus Res 44: 381-428.

33. Luis-Arteaga M, Rodrìguez-Cerezo E, Fraile A, Sàez E, Garcìa-Arenal F (1996) Different Tomato bushy stunt virus strains that cause disease outbreaks in solanaceous crops in Spain. Phytopathology 86: 535-542.

34. Qu W, Scholthof HB (2001) Effects of inactivation of the coat protein and movement genes of Tomato bushy stunt virus on early accumulation of genomic and subgenomic RNAs. J Gen Virol 82: 3107-3114.

35. Miller WA, Koev G (2000) Synthesis of subgenomic RNAs by positive-strand RNA viruses. Virology 273: 1-8

36. Lewandowski DJ, Dawson WO (2000) Functions of the 126- and 183-kDa proteins of tobacco mosaic virus. Virology 271: 90-98.

37. Qiu W, Park JW, Jackson AO, Scholthof HB (2001) Retention of a small replicase gene segment in tomato bushy stunt virus defective RNAs inhibits their helper-mediated trans-accumulation. Virology 281: 51-60.

38. Vaewhongs AA, Lommel SA (1995) Virion formation is required for the longdistance movement of red clover necrotic mosaic virus in movement protein transgenic plants. Virology 212: 607-613.

39. Martelli GP, Gallitelli D, Russo M (1988) Tombusviruses, in the plant Viruses Polyhedral Virions with Monopartite RNA Genome, Plenum Press, New York 3: $13-72$.

40. Scholthof HB, Scholthof KB, Jackson AO (1995) Identification of tomato bushy stunt virus host-specific symptom determinants by expression of individual genes from a potato virus X vector. Plant Cell 7: 1157-1172.

41. Gonçalves MC, Vega J, Oliveira JG, Gomes MMA (2005) Sugarcane yellow lea 
Citation: Fattouh FA, Ali AS, Fathy RM (2015) Further Molecular Characterization and Effect on Host Photosynthetic Pigments and Carbohydrate Pools of an Egyptian Isolate of TBSV. J Plant Pathol Microb 6: 261. doi:10.4172/2157-7471.1000261

virus infection leads to alterations in photosynthetic efficiency and carbohydrate accumulation in sugarcane leaves. Fitopatologia Brasileira 30: 10-16.

42. Sinha A, Srivastava M (2010) Biochemical changes in Mungbean plants infected Mungbean yellow mosaic virus. International Journal of Virology 6: $150-157$.

43. Funayama-Noguchi S (2001) Ecophysiology of virus-infected plants: A case study of Eupatorium makinoi infected by geminivirus. Plant Biology 3: 251-262.

44. Szigeti Z, Almási A, Sárvári E' (2002) Changes in the photosynthetic functions in leaves of Chinese cabbage infected with turnip yellow mosaic virus. Acta Bio Szeged 46: 133-138.

45. Milosevic S, Subotic A, Bulajic A, Djekic I, Jevremovic S, et al. (2011) Elimination of TSWV from Impatiens hawkerii Bull and regeneration of virusfree plant. Electronic Journal of Biotech 14: 3-4.

46. Stahl W, Sies H (2003) Antioxidant activity of carotenoids. Mol Aspects Med 24: 345-351.
47. Hull R (2002) Mathews' Plant Virology, (4thedn) Academic Press, New York, human alimentary tract. Nature 300: 637-638.

48. Xu P, Chen F, Mannas JP, Feldman T, Sumner LW, et al. (2008) Virus infection improves drought tolerance. New Phytol 180: 911-921.

49. Bolton MD (2009) Primary metabolism and plant defense--fuel for the fire. Mol Plant Microbe Interact 22: 487-497.

50. Bolouri Moghaddam MR, Van den Ende W (2013) Sweet immunity in the plant circadian regulatory network. J Exp Bot 64: 1439-1449.

51. Delaunois B, Farace G, Jeandet P, Clément C, Baillieul F, et al. (2014) Elicitors as alternative strategy to pesticides ingrapevine ? Current knowledge on their mode of action from controlled conditions to vineyard. Environmental Science and Pollution Research International 21: 4837-4846. 